\title{
Productivity of Small-Scale Yellowfin Tuna Fishing in West Region of Ceram District, Moluccas Province, Indonesia
}

\author{
Ruslan H.S Tawari ${ }^{1 *}$, Domu Simbolon ${ }^{2}$, Haruna ${ }^{1}$ \\ ${ }^{1 *}$ Fisheries and Marine Science Faculty of Pattimura University, Ambon,Indonesia
*Corresponding author : ruslan.tawari@ fpik.unpatti.ac.id
${ }^{2}$ Department of Fisheries Resources Utilization, Faculty of Fisheries and Marine Sciences,
Bogor Agricultural University, Darmaga - Bogor, Indonesia,domusimbolon@ @mail.com
${ }^{1}$ Fisheries and Marine Science Faculty of Pattimura University, Ambon,Indonesia,har_flash@yahoo.co.id
}

\begin{abstract}
Analysis on factors which influence productivity of fishing businessis an essential matter to increase fisherman income. This research aims to: 1) Analyze factors which influence productivity of small-scale yellowfin tuna fishing business, 2) Establish structure model of small-scale Yellowfin tuna fishingbusiness productivity. The analysis on factors which influence development of yellowfin tuna fishing in West Region of Seram District uses Structural Equation Model (SEM). The result of the analysis shows that Fishing Operations Material (BOP) is the primary factor which contributes $88 \%$ influence. Furthermore, Fishing Operations Unit (UOP) factor has $26 \%$ influences. Yet, Fishermen Resources (SDN) does not have any influences on small-scale yellowfin tuna fishing business. Parameter of FishingGround (DRP) has $91 \%$ influences and Fishing Season (MSP) has 79\% influences on yellowfin tuna fishing business productivity. Productivity structure of small-scale yellowfin tuna fishing has trust level of 99\%. Hence, this model of small-scale yellowfin tuna fishing productivity has well accuracy and may become reference model for tuna fisheries management especially sustainable smallscale yellowfin tuna.
\end{abstract}

Keywords_-productivity, fishing business, Yellowfin tuna, small-scale fisheries, Ceram Sea.

\section{INTRODUCTION}

Moluccas province is a potential area of Tuna-Cakalang which gives the second largest contribution in Indonesia (KKP, 2014) and located within area of "Coral Triangle Tuna" (Cabral et al, 2012; Bailey et al, 2012). Yellowfin Tuna (Thunnus albacares) is one of important fish commodities with high market demand. However, the fishing business immensely depends on the availability of fish resources and the aquatic environment. In other sides, national fisheries are still characterized by small-scale fisheries (Hermawan 2006; Tawari et al, 2014; Haruna et al, 2018).

Yellowfin tuna fishing is intensely determined by various factors either from internal factor of fish or environment factor. Production rate in fishing is determined by how big the effortof fishing which is done to utilize fish resources. Low production and productivity of yellowfin tuna fishing are generally caused by environment condition dynamics relating to fish distribution pattern, fish size, fishing season characteristic, and area of fishing (Tawari et al, 2014; Nelwanet al, 2016; Haruna et al, 2018; Haruna et al, 2019). In fact, technically production factor becomes a complicated issue in tuna fishing. The success of fishing operation is influenced by fishing tools, boat, supporting tools, and its human resources. Consequently, it needs knowledge between factor and output of production (Soekartawi, 2002; Tawariet al, 2013, Tawariet al, 2014; Sangadji, 2014).

Development of fisheries business including yellowfin tuna fishing gives social or economic impact on fishermen prosperity level if it is followed by the increasing of fishing result volume (Alhuda, 2016; Rahim and Hastuti, 2016; Maulana F, 2018). In consequences, analysis on factors which influence productivity of fishing business is an essential matter in increasing fishermen income. This research aims to: 1) Analyze factors which influence the productivity of small-scale yellowfin tuna fishing business, 2) Establish a structure model of small-scale yellowfin tuna fishingbusiness productivity.

\section{METHODOLOGY}

Time and Location of the Research

This research was performed on April 2017 - March 2018. It is located in Seram Ocean in which an operational area 
of fishermen who catch Yellowfin tuna. The sample of fishermen is spread in 9 urban villages in WestRegion of Seram District (Fig 1).

\section{Data Collection}

The collected data in this research consist of primary and secondary data which are acquired through literature review and field survey. Technique of sample collection (expert survey) is carried out with purposive sampling. The data collection is performed through questionnaire and structured interview to the fishermen (respondents) in 9 fishermen's urban villages. Questionnaire and interview assessment are carried out by using scale of Likert 1 until 5 with low until high category.

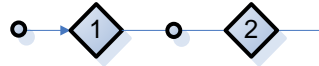

Extremely Low

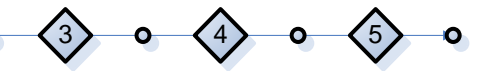

Extremely High
Sample in this research is in the number of 150 respondents of yellowfin tuna fishermen in 9 urban villages. The obtained data numbers refer to Maximum Likelihood Estimation (MLE) technique.

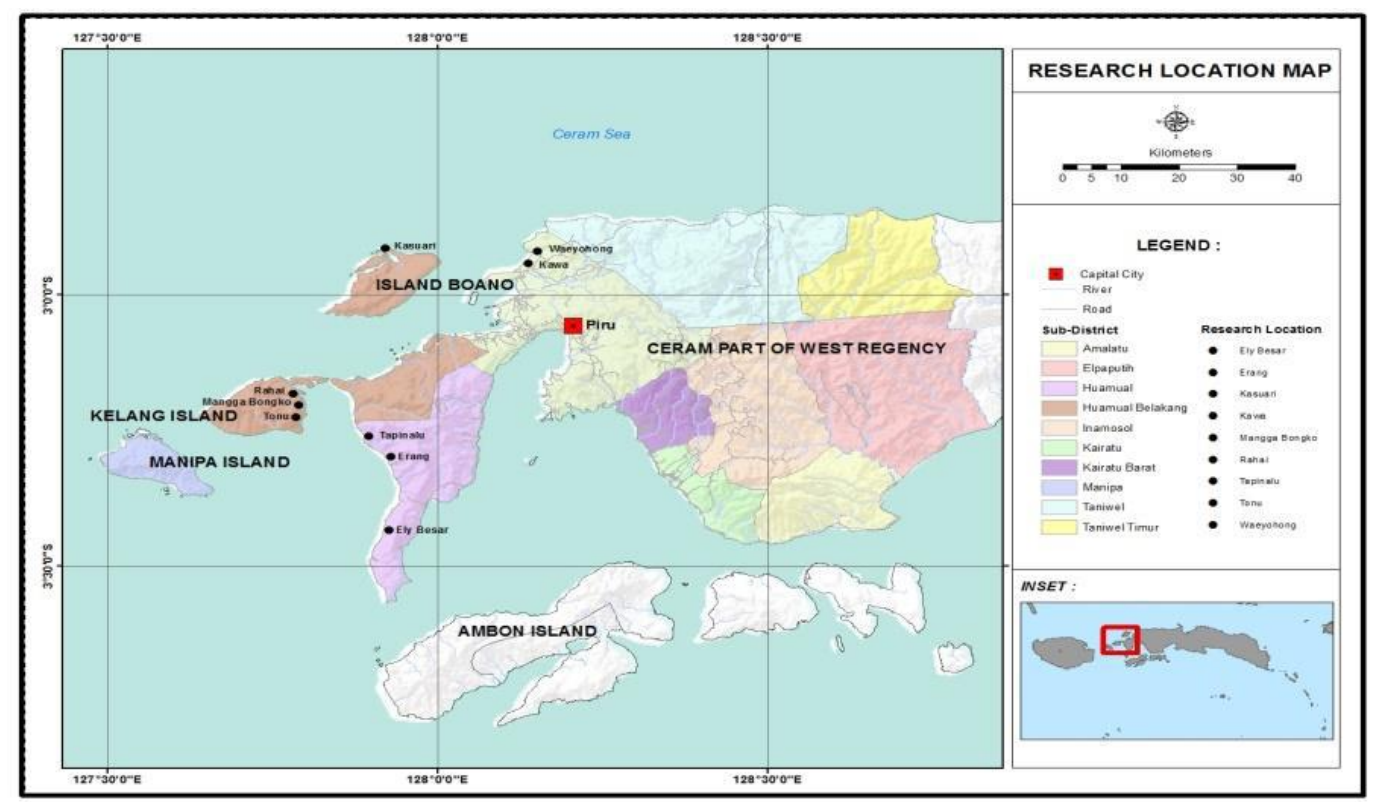

Fig 1. Maps of research location

\section{Data Analysis}

Analysis of factors which influence the development of yellowfin tuna fishing in West Ceram uses Structural Equation Model (SEM) approach. Teoretical model development is performed which involve initial design of path diagram, structural equation (structural model), and model interpretation. Afterwards, conformity test or compatibility model uses GOF (Goodness of Fitt) is conducted. Design of path diagram is presented in Fig 2.

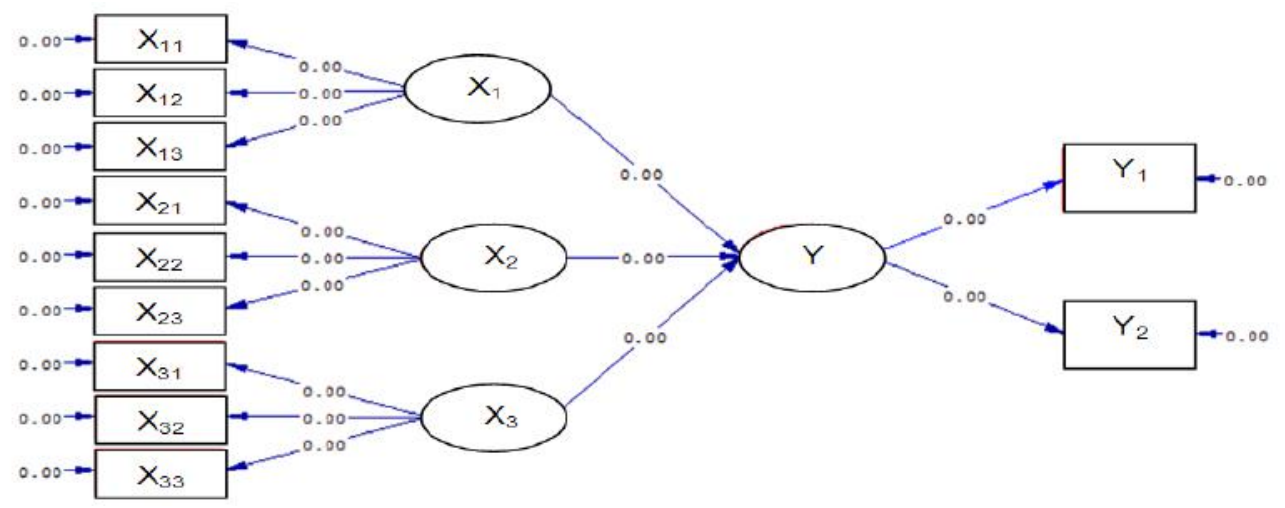

Fig 2. Design of path diagram on variable connectivity of yellowfin tuna (Thunnus albacares) fishing business 
Path diagram in this research is developed to see the interaction between the observed variables and know which interactions which have the biggest influence on productivity of small-scale yellowfin tuna fishing business in WestRegion of Seram District. After it is portrayed in a diagram, conversion into structural equaition series is performed. This equation represents causality relationship between various constructions with structur equation as follows:

Information:

$$
\eta=\gamma_{1} \xi_{1}+\gamma_{2} \xi_{2}+\gamma_{3} \xi_{3}+\zeta
$$

$\eta \quad=$ latent endogenous variable (dependent)

$\xi_{n}=$ latent exogenous variable, $\mathrm{n}=1, . ., 3$

$\zeta=$ latent errors in equations

$\gamma_{m}=$ coefficient matrix for latent exogenous, $\mathrm{m}=1, \ldots, 3$

Model compatibility test uses standard proposed by Wijanto (2008) with 15 sizes of GOF in Lisrel to assess compatibility of a SEM calculation model. Limitation and criteria to assess a model use goodness of fit.

\section{Model Interpretation}

After all of the previous steps have been conducted and the model is quite good, SEM performs interpretation. The usage of SEM is not to generate a theory, but to test model which has appropriate and well fundamental theory. Based on this idea, interpretation of the model can be accepted or prediction power from the model is not needed compared to the produced residual. The use of standardized residual covariance matrix will generate standard residual value. If interpretation towards produced residual through variable observation has bigger standard residual value from particular size, it means the model can be accepted and does not need model modification.

\section{RESULT AND DISCUSSION}

\section{Business Productivity}

Analysis result uses Structural Equation Model (SEM). There are nine (9) parameters which categorized as exogenous parameters with various connectivity levels towards three (3) latent independent variables. Furthermore, there are two (two) parameters which become endogenous variables and directly affect Yellowfin tuna fishing business productivity as the latent dependent variable in the research location. Analysis result of interaction and parameters connectivity level with latent variables is presented in form of analysis path diagram (Fig 3).

Three main factors are used as latent variable which influence yellowfin tuna fishing productivity. They are, fishing operations material (BOP), fishermen resources (SDN), and fishing operations unit (UOP). Each of those latent variables has parameter with various connectivity levels which shows the amount of influence towards independent latent variable as the determinant factor on yellowfin tuna fishing especially in the research location. In addition, there are two parameters/endogeneous variables which directly influence dependent laten variabel of yellowfin tuna productivity namely area of fishing parameter (DRP) and fishing season (MSP).

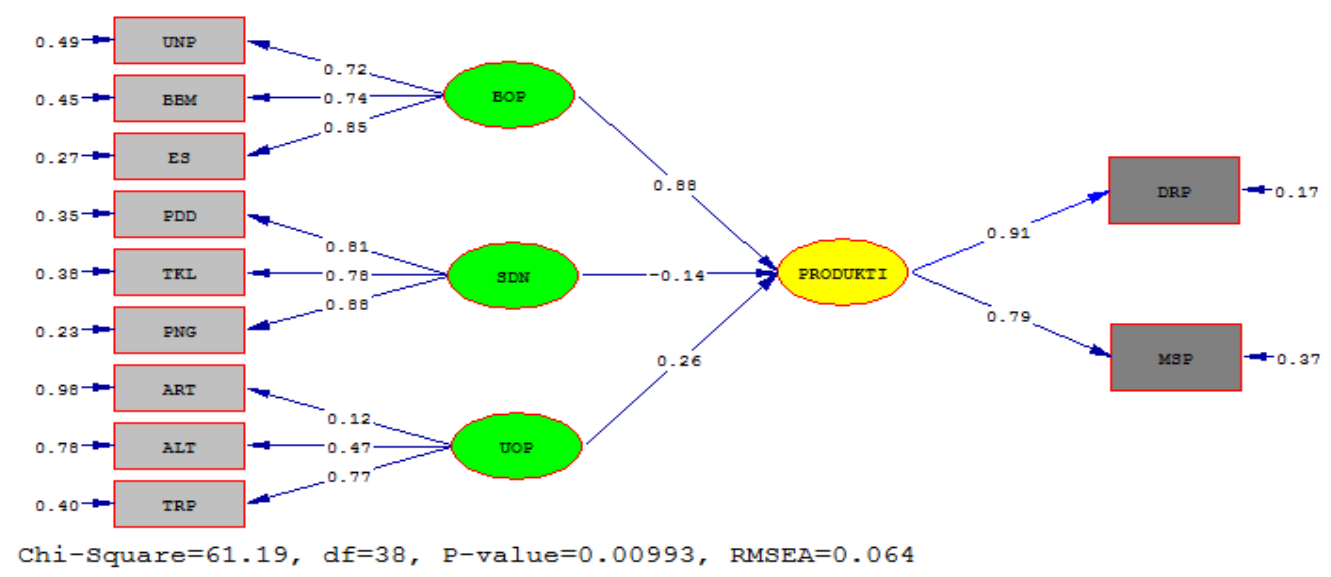

Fig 3. Connectivity and value of each element which influenceproductivity of yellowfin tuna(Thunnus albacares) fishing business

The amount of connectivity and the level of influence happenned between each factor either between exogeneous paramters with independent latent variable, independent latent variable towards dependent latent variable (productivity), or endogenous parameter towards productivivity (dependent latent variable) is a depiction of yellowfin tuna fisheries in the research location. More details are presented in Figure 3. 
Fishing operations materal (BOP) is influenced by feed parameter (UMP) fuel oil (BBM), and ice cube (ES). Analysis result shows that feed is a parameter which has the highest error variance value in amount of 0.49. After that, fuel oil and ice cube follow with error variance value respectively in amount of 0.45 and 0.27 . Error variance value posessed by each parameter is the value which depicts parameter that cannot influence independent latent variable particularly fishing operations material. The lower error variance value the better its parameter influence (observed variable) towards fishing operations material factor.

Those three assessed value have adequately big influence towards fishing operations material. Yet, ice parameter has bigger influence $(0.85)$ towards fishing operations material and then followed by fuel oil (0.74) and feed (0.72). The amount of ice parameter influence shows that dependency of fishing material is to the value of $85 \%$ towards ice availability, compared to fuel oil dan feed parameters.

Fishermen resources (SDN) are influenced by parameter of education (PDD), technology (TKL), and experience (PNG). These three determinant parameters have various error variance values. Technology mastery is parameter which has the highest error variance value in amount of 0.38 and then followed by education parameter and experience parameter with respective error variance value of 0.35 and 0.23 .

Those three parameters are deemed to have adequately big influence towards fishing operations material, but parameter of experience has the bigger influence of $88 \%$ towards fishermen resources and followed by parameter of education with $81 \%$ influence and parameter of technology with $78 \%$ influence. The amount of experience parameter influence shows dependency of fisherman resources factor towards such parameter to the value of $88 \%$.

Fishing operation unit (UOP) is influenced by fishing fleets (ART), fishing tools (ALT), and fishing trip (TRP). Parameter of fishing fleet has error variance value bigger than fishing tool and fishing trip. Fishing fleet parameter has error variance value of 0.98 , followed by fishing tool with error variance value of 0.78 and parameter of fishing trip with error variance of 0.40 . The error variance value possessed by each parameter shows the number of parameters which are not observed beyond those three observed parameters. The high error variance value of fishing fleet shows that such factor has extremely low influence towards fishing operations unit.

Based on result of path diagram as in Figure 3, it shows that the three assessed parameters have various influences on fishing operations material. Yet, correlation connectivity of fishing trip parameter has bigger influence in which $77 \%$ towards fishing operation unit, followed by fishing tool with $47 \%$ influence and fishing fleet to the value of $12 \%$. The influence amount of fishing trip parameter shows that dependency of fishing operation unit towards fishing trip parameter itself is more dominant than other parameters.

Endogeneous parameter is a parameter which has direct influence on yellowfin tuna fishing productivity (dependent variable) and can be measured as well as controlled. There are 2 endogenous parameters in which fishing ground (DRP) and fishing season (MSP). Based on analysis, fishing ground has error variance value of 0.17 and fishing season has error variance value of 0.37 . Thus, it shows that fishing ground has dominant determinant factor towards yellowfin tuna fishing productivity compared to fishing season parameter. Fishing ground is a parameter which has dominant influence with factor loading value of $91 \%$ on yellowfin tuna fishing productivity (dependent latent variable). Meanwhile, fishing season parameter only has factor loading value of $79 \%$.

The high influence of fishing ground and fishing season on yellowfin tuna fishing productivity in the research location is highly related to habitat and behavior of yellowfin tuna. Dynamics of yellowfin tuna fishing ground is temporary but it is highly influenced by environment condition and oceanograpic oceanic parameter such as sea surface temperature, chlorophyll-a, salinity, stream, depth, front, and upwelling (Zainuddin, 2013; Safruddin, 2018; Hidayat, 2019). Fishing ground influence is followed by fuel oil and ice usage on production because of tuna characteristics which always migrates so that fishing ground becomes uncertain and far away.

\section{Business Productivity Structure Model}

From basic model path diagram of the research, it shows clearly that yellowfin tuna fishing productivity is the latent variable which is influenced by two independent latent variable factors namely fishing operations material (BOP)and fishing operations unit (UOP). Among those two independent latent variables, it is found that fishing operations material has extremely big influence on Yellowfin tuna fishing productivity compared to factor of fishing operation unit. Based on result of the analysis, $88 \%$ yellowfin tuna fishing productivity is influenced by fishing operation material, followed by fishing operation unit with $26 \%$, while fishermen resources factor does not give influence on the increasing of yellowfin tuna fishing productivity and even it has loading factor with value of $0.14 \%$.

Furthermore, based on analysis result, correlation stucture of independent latent variable (BOP,UOP, SDN) on 
productivity (dependent latent variable) of yellowfin tuna fishing is in accordance with the used structure model, so that it is found structure of small-scale yellowfin tuna fishing with the following model equation structure :

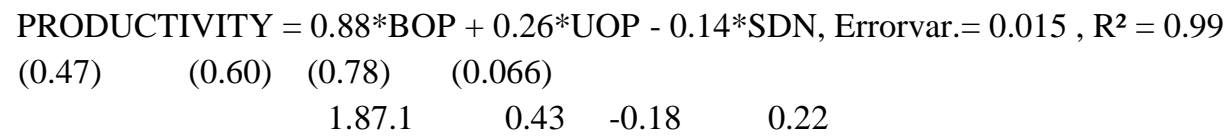

The equation above is productivity model of yellowfin tuna fishing with 9 exogeneous parameters, 2 endogeneous parameters, 3 independent latent variables, and 1 dependent latent variable. Structure model of yellowfin tuna fishing productivity in this research, as what has been presented, has determinant coefficient value $\left(\mathrm{R}^{2}\right)$ to the value of $99 \%$.

It shows that parameters and factors used as benchmark in this research can describe the condition of yellowfin tuna fishing business productivity to the value of $99 \%$ and only $1 \%$ of description by other factors which are not observed in this research. Compatibility test of structure model of small-scale yellowfin tuna fishing business productivity is presented in Table 1.

Result of model compatibility test as in Table 1 shows that there are 4 GOF sizes that depict poor compatibility and 11 GOF sizes that depict good compatibility. It indicates that compatibility of all models is good. This condition concludes that the model of this research has good accuracy level and can be used as reference model for sustainable small-scale tuna fishery management.

Table 1. Result of compatibility test for all models with GOF size

\begin{tabular}{cccc}
\hline GOF Size & Standard & Estimation Result & Accuracy \\
\hline Chi-Square & Small value & Chi-Square $=61.19$ & Poor \\
P & p $>0.05$ & $(\mathrm{P}=0.01)$ & \\
NCP Interval & Small value & 23.19 & Poor \\
& Narrow Interval & $(5.68-48.61)$ & \\
RMSEA & $0.05<$ RMSEA $\leq 0.08$ & RMSEA $=0.064$ & good fit \\
& & $\mathrm{p}=0.21$ & \\
ECVI & Small value and close to & $\mathrm{M}^{*}=0.79$ & good fit \\
& ECVI saturated & $\mathrm{S}^{*}=0.89$ & \\
AIC & & $\mathrm{I} *=5.65$ & good fit \\
& Small value and close to & $\mathrm{M}=117.19$ & \\
& AIC saturated & $\mathrm{S}=132.00$ & good fit \\
CAIC & & $\mathrm{I}=842.22$ & \\
& Small value and close to & $\mathrm{M}=229.49$ & good fit \\
NFI & CAIC saturated & $\mathrm{S}=396.70$ & good fit \\
NNFI & NFI $\geq 0.90$ & $\mathrm{I}=886.34$ & good fit \\
CFI & NNFI $\geq 0.90$ & 0.93 & good fit \\
IFI & CFI $\geq 0.90$ & 0.96 & Poor \\
RFI & IFI $\geq 0.90$ & 0.97 & good fit \\
CN & RFI $\geq 0.90$ & good fit \\
RMR & CN $\geq 200$ & 0.97 &
\end{tabular}

Information : $M=$ model $; S=$ saturated $;=$ Independence

\section{CONCLUSION}

1. Two main factors in this model are Fishing Operation Material (BOP) and Fishing Operation Unit (UOP) with six parameters in which feed (UMP), fuel oil
(BBM), ice cube (ES), fishing fleets (ART), fishing tools (ALT), and fishing trip (TRP). In addition, including two parameters of environment in which fishing ground (DRP) and fishing season (MSP) which 
influence small-scale yellowfin tuna fishing business productivity in WestRegion of Seram District.

2. Correlation structure of independent latent variable Fishing Operation Material (BOP), Fishing Operation Unit (UOP), and fishermen resources (SDN) on productivity (dependent latent variable) satisfies requirements of structure model on small-scale tuna fishing business productivity.

\section{REFERENCES}

[1] Bailey M, Jimely Flores, Sylvester Pokajam, U. Rashid Sumaila, 2012. Towards better management of Coral Triangle tuna. Ocean \& Coastal Management. Elseiver.

[2] Cabral R, Trinidad A.C, Geronimo R, and Alin P, 2012. Opportunities and Challenges in the Coral Triangle. Enviromental Science and Technology. American Chemical Society

[3] Haruna, Mallawa A., Musbir, Zainuddin M, 2018. Population dynamic indicator of the yellowfin tuna Thunnus albacares and its stock condition in the Banda Sea, Indonesia. AACL Bioflux 11(4):13231333

[4] Haruna, Agustinus Tupamahu, and Achmar Mallawa, 2019. Minimizing the Impact of Yellowfin Tuna Thunnus albacares fishing in Banda Sea. International Journal of Environment, Agriculture and Biotechnology (IJEAB) Vol-4, Issue-1, Jan-Feb2019 , ISSN: 2456-1878 http://dx.doi.org/10.22161/ijeab/4.1.16

[5] Hermawan D, 2011. Desain pengelolaan perikanan yellowfin tuna (Thunnus albacares) di perairan ZEEI samudera hindia selatan Jawa Timur, Disertasi. Institut Pertanian Bogor, Bogor, (in Indonesia)

[6] Hidayat R , Zainuddin M , Safruddin S , Mallawa A and Farhum S A, 2019. Skipjack Tuna (Katsuwonus pelamis) catch in relation to the Thermal and Chlorophyll-a Fronts during May - July in the Makassar Strait. IOP Conf. Series: Earth and Environmental Science $253 \quad$ (2019) 012045. doi:10.1088/1755- 1315/253/1/012045

[7] KKP, 2014. Laporan Kinerja. Kementerian Kelautan dan Perikanan Republik Indonesia Tahun 2014 (in Indonesia)

[8] Alhuda S, Anna Z, and Rustikawati I, 2016. Analysis of Productivity and Business Performance Purse Seine Fishermen at Lempasing Coastal Fishing Port, Bandar Lampung. Jurnal Perikanan Kelautan Vol. VII No. 1 /Juni 2016 (30-40) (in Indonesia)
[9] Maulana Firdaus, 2018. The Profile of Tuna and Cakalang Fishery in Indonesia. Buletin Ilmiah "MARINA" Sosial Ekonomi Kelautan dan Perikanan Vol. 4 No.1 Tahun 2018: 23-32 (in Indonesia)

[10] Nelwan AFP, Sudirman, Zainuddin M, Kurnia M2016.Large Pelagic Fisheries Productivity by Using Handline Based in Majene District. Marine Fisheries ISSN 2087-4235 Vol. 6, No. 2, November 2015 Hal: 129-142 (in Indonesia)

[11] Rahim and Hastuti, 2016. Determinants of Traditional Fishing Income in West Coast of Barru Regency. J. Sosek KP Vol. 11 No. 1 Juni 2016: 75-88 (in Indonesia)

[12] Safruddin, Dewi Y.K, Hidayat R, Umar M.T, Zainuddin M, 2018. Study of the Oceanographic Conditions of Fishing Grounds of LargePelagic Fish using Pole and Line in the Gulf of Bone Waters. Prosiding Simposium Nasional Kelautan dan Perikanan V Universitas Hasanuddin, Makassar, 5 Mei 2018 (in Indonesia)

[13] Sangadji Selfi, 2014. Study Development Of Tuna Fishing Based Community In Ambon City. Tesis. Institut Pertanian Bogor, Bogor (in Indonesia)

[14] Soekartawi. 2002. Teori Ekonomi Produksi dengan Pokok Bahasan Analisis Fungsi Produksi CobbDouglas. PT. Raja Grafindo Persada. Jakarta (in Indonesia)

[15] Tawari R.H.S, Simbolon D, Purbayanto A, Taurusman A.A, 2013. Sharing System for Small Scale of Yellowfin Fishing in the West Seram Distric. BULETIN PSP ISSN: 0251-286X Volume 21 No. 2 Edisi Agustus 2013 Hal 237-245

[16] Tawari R.H.S, Simbolon D, Purbayanto A, Taurusman A.A, 2014. Fishing Fleet Optimization Analysis of Small Scale Yellowfin Tuna in West Seram Regency. Marine Fisheries, ISSN 2087-4235 Vol. 5, No. 2, November 2014. Hal: 129-137(in Indonesia)

[17] Wijanto, S.H, 2008. Structural Equation Modeling dengan Lisrel 8.8, Konsep dan Tutorial. Graha Ilmu. Jogjakarta (in Indonesia)

[18] Zainuddin M, Nelwan A.F, Farhum A., Hajar M.A.I, Najamuddin, Kurnia M, and Sudirman. 2013. Characterizing Potential Fishing Zone of Skipjack Tuna during the Southeast Monsoon in the Bone Bay-Flores Sea Using Remotely Sensed Oceanographic Data. International Journal of Geosciences, Vol. (4): 259-266. 